\title{
A new species of Condea (Lamiaceae: Ocimeae: Hyptidinae) and a new combination, from the Americas
}

\author{
Raymond M. Harley ${ }^{1,2}$
}

Summary. A brief historical account of the genus Condea (Lamiaceae) is followed by a note on a new species from Brazil and a new combination in Condea from Mexico. For C. petrensis, a detail of its discovery in the outskirts of Rio de Janeiro, a description, diagnosis and illustration are provided. Its conservation status is Critically Endangered, following the criteria of IUCN. A key to South American species of Condea sect. Condea is presented, with notes on their distribution and taxonomy.

Resumo. É apresentado um breve histórico do gênero Condea (Lamiaceae), seguido pela publicação de uma nova espécie do Brasil e uma combinação nova de Condea do México. Para C. petrensis são incluídos uma nota sobre a descoberta da mesma nos arredores da cidade do Rio de Janeiro, diagnose, descrição e ilustração. Foi classificada segundo os critérios da IUCN como Criticamente Ameaçada. Também é apresentada uma chave de identificação para as espécies de Condea da América do Sul, incluindo nota sobre distribuição e taxonomia.

Key Words. Brazil, Condea macvaughii, Hyptis, Mexico, Rio de Janeiro.

\section{Introduction}

The present paper is in part an adjunct to that published by Harley \& Pastore (2012), in which the genus Hyptis Jacq. (Lamiaceae), at that time with almost 300 species, was divided among 12 genera, of which nine were new. This followed on from an earlier paper (Pastore et al. 2011), in which a molecular analysis had shown that the genus Hyptis was seriously paraphyletic. It is necessary to explore the historical background, to see how the present classification of the Hyptidinae took shape, based largely on the work of Bentham (1833, 1848) and Epling (1949), in which Condea Adans. is placed.

In the $18^{\text {th }}$ and early $19^{\text {th }}$ century, there was much confusion over generic concepts in the Lamiaceae (Labiatae). Tropical American species discovered at that time, which were later to be assigned to subtribe Hyptidinae Endl. (Endlicher 1838), were often consigned to well-known European genera, such as Ballota L., Nepeta L., Satureja L. and Bystropogon L'Hérit. by Linnaeus and his contemporaries (Linnaeus (1759: 1097, 1100), Richard, L. (1792: 110), Poiret in Lamarck (1805: 571), L'Héritier (1787: 12). It was not until Bentham, in a series of papers, culminating in a revision of the entire family (Bentham 1833), brought order out of chaos, completing the basis on which all subsequent taxonomic progress on the family rested.
A botanist working in Jamaica in the Caribbean, Patrick Browne, was the first to validly publish a genus: Mesosphaerum P.Browne (1756: 257), which was based on a species of Hyptidinae. However, the species which he described was given a polynomial: Mesosphaerum "Hirsutum, foliis cordatis serrate-subsinuatis, floribus verticilliter spicatis", and therefore remained invalid until Linnaeus published it in the genus Ballota L. as B. suaveolens L. (Linnaeus 1759). Seven years after the creation of Mesosphaerum by Browne, Adanson (1763) published another genus Condea Adans. also based on a species of Hyptidinae. He too, failed to make a valid species combination in the genus, merely listing Satureja americana, as a constituent species. Later, Jacquin (1787: 101), created the genus Hyptis Jacq., in which he included two species from the Caribbean, with small, rather insignificant flowers with a hinged anterior corolla lip, but each with remarkably different inflorescences. One of these, Hyptis capitata Jacq., with flowers in capitula, was destined to become the generic type of Hyptis (Green 1929: 107).

However, it was a French botanist, Pierre Antoine Poiteau (1806), who took up the name Hyptis, and published an account of 15 species, transferring some which had been wrongly placed in other genera, including Hyptis suaveolens (L.) Poit., as well as describing eight new species. Five of these are still

\footnotetext{
Accepted for publication 23 January 2019. Published online 15 March 2019

1 Royal Botanic Gardens, Kew, Richmond, Surrey, TW9 3AB, UK.

2 Programa de Pós-Graduação em Botânica, Universidade Estadual de Feira de Santana, Av. Transnordestina s.n., Novo Horizonte, Feira de Santana, Bahia, 44036-900, Brazil. e-mail: rharley05@hotmail.com
} 
recognised within Hyptis, today. Later, Otto Kuntze (1891: 525) discovered that there were two generic names for the group earlier than Hyptis, Mesosphaerum and Condea, and that the earlier of these, Mesosphaerum, should take precedence over Hyptis. He therefore recombined all known species of Hyptis (in all about 250 names), transferring them to Mesosphaerum.

These were not the only name changes made by Kuntze, and it was generally felt by botanists of the day that nomenclatural stability was more desirable than strict priority. In the case of Mesosphaerum and Condea, both of which predated Hyptis, it was considered necessary to dispose of them by conserving the genus Hyptis against them, and this was done by Briquet (1906). As the two former genera were based on different types from that of Hyptis, there was always the possibility that they could again become available, if ever the genus Hyptis were to be broken up. This occurred, as a result of molecular phylogenetic studies (Pastore et al. 2011, and Harley \& Pastore 2012), when both genera were resurrected. The second species described by Jacquin, as Hyptis verticillata Jacq., is now placed in the genus Condea as C. verticillata (Jacq.) Harley \& J.F.B.Pastore (2012: 15).

The tribe Ocimeae, subfam. Nepetoideae (Lamiaceae) to which the genus Condea, a member of the subtribe Hyptidinae belongs, is characterised by having declinate stamens, positioned close to the anterior corolla lip. The predominantly New World subtribe Hyptidinae is characterised by the stamens being enclosed within a boat-shaped anterior corolla lip (except in the Central American genus Asterohyptis, which has a greatly reduced corolla). The lip of the corolla has an elastic hinge at its base, holding the stamens under tension, to be released explosively, when a pollinator causes the corolla lip to suddenly flick back (Harley et al. 2004; Harley 1971).

Condea at present consists of 26 species, with a distribution ranging through much of tropical America. All species have at one time been included in the genus Hyptis. Condea is characterised by an often spiciform or raceme-like or diffusely paniculate thyrse of pedunculate or sessile, 1- to many-flowered cymes. The intercalary cyme-axes are contracted so that those species with pedunculate cymes, are \pm subumbellate in form, and those with sessile cymes have flowers in fascicles or verticils, from the axils of subtending bracts. The flowers, which are medium-sized to small, are usually pedicellate, sometimes long-pedicellate. The gynoecium has a deciduous style, usually falling with the corolla, and lacks a persistent stylopodium.

Two sections are currently recognised (Harley \& Pastore 2012): sect. Condea (typified by Condea verticillata) with 16 species, which occur mainly in the Caribbean, with one widespread species extending through southern Florida and Central America to the northern Andes, and another group in southern
Brazil, Paraguay, Argentina and Bolivia. It is distinguished by having flowers solitary or in fascicles, in the axils of reduced or leafy bracts, and an indumentum of simple hairs. Six species of Condea sect. Condea are currently recorded from South America, not including the new species described below. All but one of these, Condea verticillata, occur in Brazil (BFG 2015).

The other section: sect. Laniflorae (Epling) Harley \& J.F.B.Pastore (typified by Condea laniflora (Benth.) Harley \& J.F.B.Pastore), occurs mainly in Central America (c. 10 species), with two other species in the Andes. These typically have dendroid hairs and flowers often in sub-umbellate, pedunculate clusters (see Harley \& Pastore 2012).

Additional to the foregoing statistic, is a new species, described below, in this paper, from Rio de Janeiro state, Brazil.

\section{Material \& Methods}

In the course of many years' study of the Lamiaceae of Tropical America and especially of the subtribe Hyptidinae, extensive fieldwork, not only in Brazil, but also other in many other countries, was undertaken and many herbaria visited, not only in Tropical America but also in North America and Europe. As a result, a vast range of material has been examined. Collections of the new species from RB, B and from UC (Berkeley, California) were received for determination. The observations were compared with notes on, and images of, other herbarium material of Condea from $\mathrm{K}$ and from many other herbaria. These studies, together with an examination of the relevant bibliography, allowed the author to recognise this as a new and undescribed species. Herbarium acronyms follow Thiers (continuously updated), and conservation categories follow the IUCN Red List Criteria (IUCN 2016).

\section{Taxonomic Treatment}

No new South American species of this group, now treated as members of the genus Condea, had been recognised since Hyptis thyrsiflora Epling (1936) was published over 80 years ago. In the course of examining undetermined specimens from the Rio de Janeiro Botanic Garden, the author discovered an apparently unpublished new species, collected by Santos Lima \& Brade, from one of the steep mountains that arise around the bay of Guanabara.

So far, three duplicates of this type collection, made over 80 years ago, have been located, only one of which can be found in the RB herbarium. Another duplicate, was sent to the author from the Berlin Herbarium (B), and a third, which had been annotated by Epling is now in UC (Berkeley, California), Epling determined it as "Hyptis (?) salviaefolia", but this is quite clearly erroneous. This name is today more correctly known as Eriope salviifolia (Pohl ex Benth.) 
Harley. The specimen housed in RB repeats Epling's original determination, but there is a separate brown slip of paper with, written in pencil in an unrecognised hand, "H. eriocalyx St. Hil." and then underneath: "? = H. fasciculata var. tomentosa". The type of $H$. eriocalyx A.St.-Hil. ex Benth. (Bentham 1833: 130), which is found in the Paris herbarium (P!) is a rather hairy form of another species: Condea undulata (Schrank) Harley \& J.F.B.Pastore, while Hyptis fasciculata var. tomentosa Schmidt (in Martius 1858: 142) is based on Pohl 3768, which can be seen in the Vienna herbarium (W), and is also the type of the earlier Hyptis fasciculata Benth. var. tomentella Benth. (Bentham 1848: 129). Both these varieties are now correctly synonymised under Condea undulata. In the account below, all specimens have been seen by the author. The new species is here described below:

Condea petrensis Harley sp. nov. Type: Brazil. Rio de Janeiro. Município: Sta. Madalena, Pedra Dubois, 28 Jan. 1934, J. Santos-Lima E A A. C. Brade 13272 (holotype $\mathrm{RB}$; isotypes $\mathrm{B}, \mathrm{UC}$ ).

http:/ /www.ipni.org/urn:lsid:ipni.org:names:60477983-2

Erect subshrub, at least up to $60 \mathrm{~cm}$ high. Stems quadrangular, up to $4-5 \mathrm{~mm}$ diam., rather densely pilose with long, weak, patent trichomes and some glandtipped trichomes. Cauline leaves with petioles $0.5-1.6 \mathrm{~cm}$ long, lamina $4.8-6.5 \times 2.6-3.7 \mathrm{~cm}$, discolorous, membranous, broadly ovate-lanceolate or sometimes ovate, apex \pm obtuse, base rounded or slightly truncate, margin finely serrate, with up to c. 30 teeth on each side of larger leaves, adaxial surface green, rather sparsely, but evenly, hairy with short, curved, rigid trichomes with sharply acute apex, veins slightly impressed, abaxial surface greyish green, more densely pilose, with long, weak, slender trichomes, especially along the prominent midrib and veins, and with scattered sessile glands, smaller veins reticulate, dark. Inflorescence an elongate, much branched thyrsoid panicle, bearing a series of up to 3 - 4-flowered verticils, the flowers in lax fascicles, or rarely solitary, from the axils of foliaceous bracts c. $2.5 \times 0.7 \mathrm{~cm}, \pm$ elliptic-oblong, which decrease in size upwards, toward inflorescence apex. Flowers subtended by linear bracteoles, $2-3 \times 0.2-0.3 \mathrm{~mm}$, and borne on pedicels $1.5-3.3 \mathrm{~mm}$ long, calyx at anthesis c. $2.7 \mathrm{~mm}$ long, tube c. $2 \mathrm{~mm}$ long, infundibuliform, membranous, externally densely and conspicuously hairy with long, rigid, patent trichomes, extending onto the pedicel, and with scattered glandtipped trichomes and sessile glands, internally glabrous, except at throat, calyx lobes subequal, $0.6-0.7 \mathrm{~mm}$, membranous, broadly deltate and slightly spreading, less hairy than tube and weakly ciliate, fruiting calyx accrescent, 5.0 - $5.5 \mathrm{~mm}$ long, tube $3.8-4.5 \mathrm{~mm}$ long, more or less cylindrical, slightly swollen below to encom- pass nutlets, and slightly flaring below throat, externally densely hairy, internally glabrous except just below throat, calyx lobes $0.8-1 \mathrm{~mm}$ long, deltate and slightly paleaceous with darker reticulum of veins. Corolla white to pale lilac or pink, c. $4.5 \mathrm{~mm}$ long, externally sub-glabrous, tube $3 \mathrm{~mm}$ long, c. $0.8 \mathrm{~mm}$ in diam., glabrous within, anterior lobe boat-shaped, reflexing, with short apiculus, stamens with filaments hairy, those of posterior stamens densely so, style glabrous, stylopodium absent, the two stigmatic lobes short. Nutlets $2.0-2.1 \times 1.0-1.2 \mathrm{~mm}$, usually only one developing in each flower, narrowly oblong-ellipsoid with apex asymmetric, slightly incurved, oblique, introrsely curved, pericarp castaneous, glabrous, smooth to minutely punctulate, not mucilaginous when wet, base with 2 pale whitish abscission scars; swollen corky appendages, visible in some species on outer surface of nutlet, absent. Fig. 1.

RECOGNITION. Condea petrensis is an erect shrub, to at least $60 \mathrm{~cm}$ tall, with membranous, ovate-lanceolate to ovate petiolate leaves $2.6-3.7 \mathrm{~cm}$ wide, and with a diffuse, terminal, thyrsoid panicle of flowers, arranged in 1- to 4flowered verticils. Of the six species of Condea sect. Condea which occur in South America, it is most similar to C. floribunda (Briq.) Harley \& J.F.B.Pastore, C. elegans (Briq.) Harley \& J.F.B.Pastore and C. thyrsiflora (Epling) Harley \& J.F.B.Pastore, all of which have similar diffuse inflorescences. The other species, such as C. undulata, C. fastigiata (Benth.) Harley \& J.F.B.Pastore and C. verticillata have more slender, less branched, spiciform inflorescences. From $C$. elegans, the new species can be distinguished by its flowers on shorter pedicels $1.5-3.3 \mathrm{~mm}$ long (10 $15 \mathrm{~mm}$ long in C. elegans); from C. thyrsiflora it is distinguished by the ovate-lanceolate to ovate leaves, with a rounded to truncate base and $4.8-6.5 \mathrm{~cm}$ long (leaves elliptic-lanceolate, with a long-attenuate base and up to $7-13 \mathrm{~cm}$ long in C. thyrsiflora), and with the fruiting calyx tube $3.8-4.5 \mathrm{~mm}$ in C. petrensis (c. $3 \mathrm{~mm}$ long in C. thyrsiflora). From C. floribunda, the new species can be distinguished by the fruiting calyx with tube $3.8-$ $4.5 \mathrm{~mm}$ long, and the calyx lobes $0.8-1.0 \mathrm{~mm}$ long in C. petrensis $(3.0-3.5 \mathrm{~mm}$ long and $0.5 \mathrm{~mm}$ long respectively in C. floribunda). Condea petrensis also occurs far from the range of these other species, none of which occurs in the State of Rio de Janeiro.

DISTRIBUTION. The species is known from only two collections, both from the same locality in the State of Rio de Janeiro, Santa Maria Madalena (Mun.): Pedra Dubois.

SPECIMENS EXAMINED. Brazil. Rio de Janeiro. Município: Sta. Madalena, Pedra Dubois, 28 Jan. 1934, J. Santos-Lima $\mathcal{E}$ A. C. Brade 13272 (holotype RB; isotypes B, UC); Santa Maria Madalena (Mun.): Pedra Dubois, $21^{\circ} 58^{\prime} \mathrm{S}$, $42^{\circ} 01^{\prime} \mathrm{W}, 1195 \mathrm{~m}$ alt., rock outcrop on exposed slope, shrub $60 \mathrm{~cm}$ tall, flowers white to pale pink, $22 \mathrm{Feb} .1983$, T. Plowman E $\mathcal{O}$ H. C. Lima 12877 (F).

HABITAT. Rock outcrop on exposed slopes.

CONSERVATION STATUS. In view of its rarity, and its semiurban situation, the survival of Condea petrensis must be 


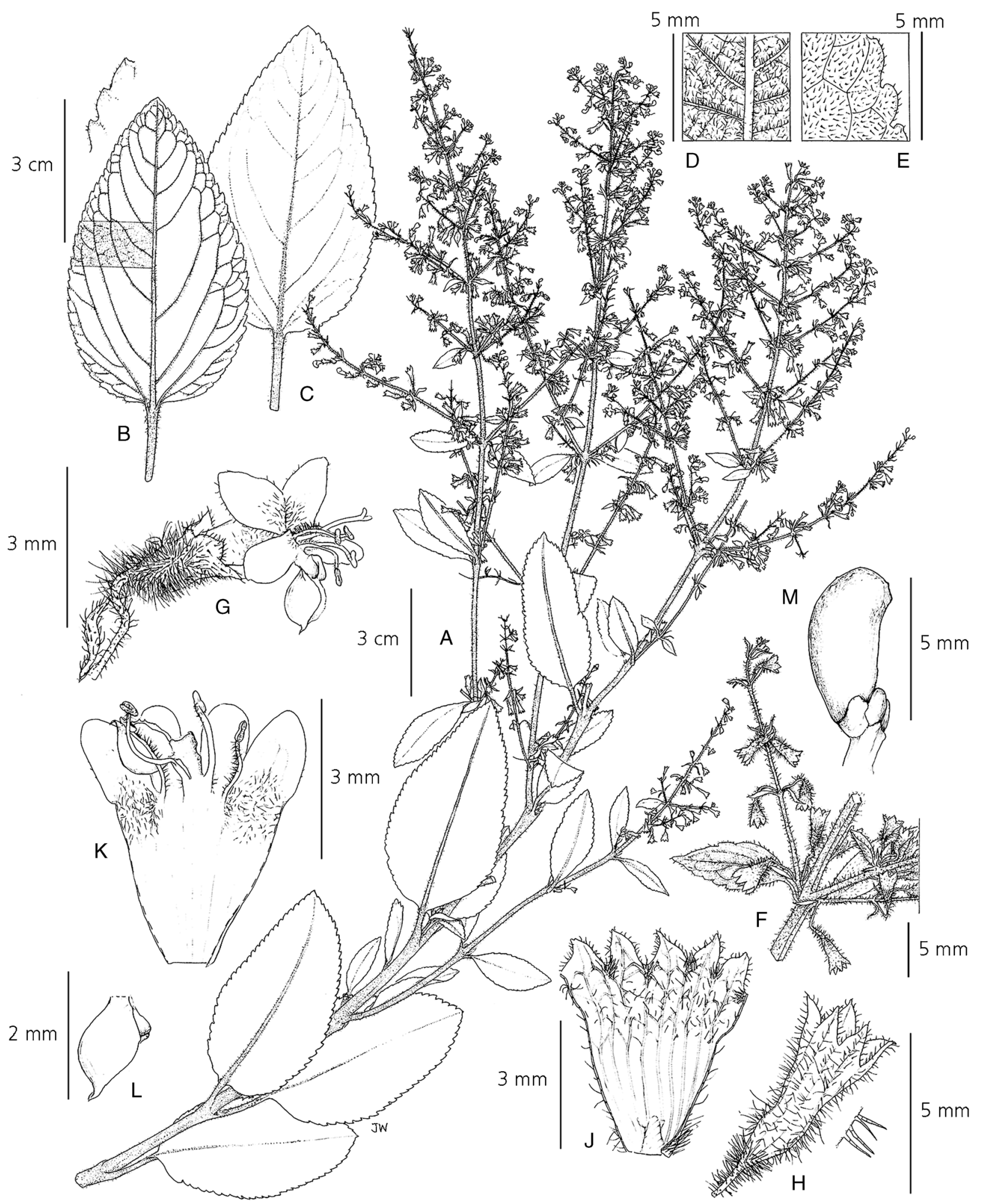

Fig. 1. Condea petrensis. A habit; B cauline leaf abaxial surface; C cauline leaf adaxial surface; D cauline leaf, abaxial surface, indumentum detail; $\mathbf{E}$ cauline leaf, adaxial surface, detail; $\mathrm{F}$ detail of inflorescence branch; $\mathrm{G}$ flower, side view; $\mathrm{H}$ fruiting calyx, side view; J fruiting calyx opened out to display interior; $\mathrm{K}$ corolla opened out to display interior; $\mathrm{L}$ anterior corolla lobe, side view, displaying swollen hinge; M nutlet side view. All from Santos Lima \& Brade A. C. 13272 (holotype: RB). DRAWN BY JULIET BEENTJE. 
considered extremely precarious, the habitat is frequented by people and is probably vulnerable to fires. Indeed, as it was last seen over 30 years ago, there is the question as to whether it still exists. Hopefully these questions could be remedied by a further visit to the area. As it is so far only known at a single site, with no information as to population size, it should be considered as Critically Endangered, according to IUCN criteria (2016).

PHENOLOGY. Flowering January and February. ETYMOLOGY. From the Latin "petrensis": found among rocks (Stearn 2004).

NOTE. The holotype specimen is at the flowering stage, and mature fruiting material is very scarce. Five fruiting calyces were found and examined. These were all very similar. Each had only a single mature nutlet, the other three remaining undeveloped. The asymmetric nutletapex has notsofar been observed elsewhere in the genus and has not been recorded in other species of Hyptidinae.

\section{Synopsis and key to South American species of Condea Adans.}

Nine species of Condea are currently recorded from Tropical America, six of which occur in Brazil (Lista da Flora do Brasil on-line). The genus has been divided into two sections.

\section{Key to sections of Condea}

Flowers solitary or in fascicles, in the axils of reduced or leafy bracts, trichomes simple, uniseriate . sect. Condea Flowers in subumbellate, pedunculate cymes, or if cymes \pm sessile, then trichomes dendroid . . . . . . sect. Laniflorae

\section{Condea sect. Condea}

The section has two main centres of diversity. One in the Caribbean and Central America, with 17 species: eight restricted to the Caribbean, two species restricted to Central America, and one widespread species, extending from the Caribbean to SE United States, Central and NW South America, and a second centre, with six species in South-eastern South America: Paraguay, Brazil, Uruguay and Argentina.

\section{Key to South American species of Condea section Condea}

1. Inflorescence a diffusely branched panicle, flowers with fruiting pedicels often more than 3 mm, sometimes to

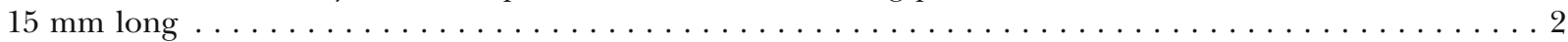

1. Inflorescence a slender spiciform, usually interrupted thyrse, flowers subsessile or up to $3 \mathrm{~mm}$ long in fruit ..5

2. Flowers with fruiting pedicels $10-15 \mathrm{~mm}$ long. Calyx in fruit with tuft of white hairs in throat. .1. C. elegans

2. Flowers with fruiting pedicels less than $10 \mathrm{~mm}$ long. Calyx in fruit without tuft of white hairs in throat . . . . . 3

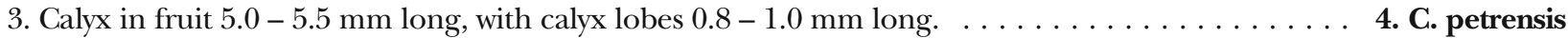

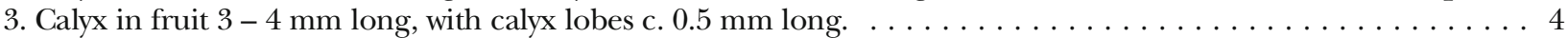

4. Leaves with lamina $7-13$ mm long, elliptic-lanceolate with long attenuate base. . . . . . . . . . 3. C. thyrsiflora

4. Leaves with lamina 3.5 - 7.5 mm long, ovate, often narrowly so with cuneate to truncate base. . . . 2. C. floribunda

5. Leaves with lamina usually narrowly elliptic-lanceolate, with base long-attenuate into the petiole. Fruiting calyx c. $2.6 \mathrm{~mm}$ long. Species widespread from North and Central America, Caribbean and the northern Andes, not

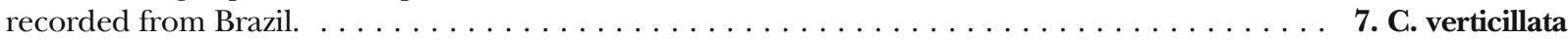

5. Leaves with lamina ovate-acuminate to broadly lanceolate, with base truncate to slightly cordate. Fruiting calyx $2.5-$ $5.5 \mathrm{~mm}$ long. Species occurring in South and Eastern Brazil Uruguay, E. Paraguay and N. Argentina. . . . . . . . 6

6. Inflorescence more slender, often curved and nodding, lateral branches not fastigiate, verticillasters congested or not. Fruiting pedicels to $1.5 \mathrm{~mm}$ long. Calyx broadly campanulate, widest at mouth, lobes $1-1.25 \mathrm{~mm}$ long, usually broader than long, deltate and conspicuously spreading, (often pink-tinged). . . . . . . . . . 5. C. undulata

6. Inflorescence erect \pm rigid, lateral branches usually short, fastigiate, verticillasters usually congested. Fruiting pedicels to $1-4 \mathrm{~mm}$ long. Calyx tubular, not widest at mouth, lobes $0.5-1 \mathrm{~mm}$ long, broad at base, but abruptly acuminate with almost subulate tip. $\ldots \ldots \ldots \ldots \ldots \ldots \ldots \ldots \ldots \ldots \ldots \ldots \ldots \ldots \ldots \ldots \ldots$. fastigiata

1. Condea elegans (Briq.) Harley EJ J.F.B.Pastore (2012: 13). Eriope elegans Briq. (Briquet 1889); Hyptis elegans (Briq.) Briq. (Briquet 1897); Hyptis gracilipes Britton (1893). DISTRIBUTION. Brazil: Mato Grosso do Sul, Paraná, Rio Grande do Sul. S \& SE Paraguay. NE Argentina (O'Leary 2015).

2. Condeafloribunda (Briq.) Harley EJ J.F.B.Pastore (2012: 14). Hyptis floribunda Briq. (Briquet 1897); Hyptis elegans var. campicola Briq. (Briquet 1897).
DISTRIBUtION. Brazil: Mato Grosso do Sul, Paraná, Santa Catarina, Rio Grande do Sul; Uruguay, N \& SC Paraguay, N Argentina (O'Leary 2015). (Introduced in Mauritius and Florida U.S.A.)

3. Condea thyrsiflora (Epling) Harley E J.F.B.Pastore (2012: 14). 
Hyptis thyrsiflora Epling (1936).

DISTRIBUtION. Brazil: Minas Gerais, Paraná, São Paulo.

\section{Condea petrensis Harley}

DISTRIBUTION. Brazil: Rio de Janeiro.

5. Condea undulata (Schrank) Harley E J.F.B.Pastore (2012: 14).

Hyptis undulata Schrank (1822); Hyptis fasciculata Benth. (Bentham 1833);

Hyptis eriocalyx A. St.-Hil. ex Benth. (Bentham 1833); Hyptis fasciculata Benth. var. tomentella Benth. (Bentham 1848).

DISTRIBUTION. Brazil: Bahia, Distrito Federal, Espirito Santo, Minas Gerais, Pernambuco, Paraná, Rio de Janeiro, Santa Catarina, Rio Grande do Sul, São Paulo. (The record from Distrito Federal is probably an introduction); Uruguay. NOTE. This and the following species have, in the past often been considered conspecific. Although treated as separate by Bentham (1833: 130), Schmidt (1858: 142) reduced Hyptis fastigiata to varietal status under Hyptis fasciculata. Epling (1949: $244-5)$, however, treated the two as synonymous, commenting in an unpublished note "the species (H. fasciculata) is reasonably variable, but I do not believe that the varieties proposed represent very well-defined geographical races". However, with a large increase in number of collections available, the present author observed that the two taxa did indeed display different geographical, although partly overlapping, distributions, and could be distinguished morphologically. He therefore recognised the two as distinct subspecies (Harley
1985: 10 - 15). Some years later, he was able to examine both taxa in the field in Southern Brazil, noting that even when growing in the same area, they remained distinct, and he observed further differences not previously detected. As a result, their taxonomic status has reverted to that originally proposed by Bentham: as two distinct species (Harley \& Pastore 2012: 14).

\section{Condea fastigiata (Benth.) Harley $\mathcal{E}$ J.F.B.Pastore} (2012: 14).

Hyptis fastigiata Benth. (Bentham 1833); Hyptis fasciculata var. fastigiata (Benth.) Schmidt (1858); Hyptis fasciculata subsp. fastigiata (Benth.) Harley (1985); Hyptis diaphora Briq. (Briquet 1896).

DISTRIBUtION. Brazil: Paraná, Rio Grande do Sul, Minas Gerais, Santa Catarina, São Paulo; Uruguay. S \& SE Paraguay. N Argentina (O'Leary 2015).

\section{Condea verticillata (Jacq.) Harley E J.F.B. Pastore (2012: 15). \\ Hyptis verticillata Jacq. (Jacquin 1787).}

DISTRIBUTION. South America: Trinidad, Colombia, Ecuador. Extending to: USA: Florida, Greater Antilles: Cuba, Hispaniola, Jamaica. Lesser Antilles: Barbados, Guadaloupe, Dominica, Grenada, Puerto Rico, Martinique, St. Lucia, St Vincent. Central America: Southern Mexico, Costa Rica, Honduras, Guatemala, Belize, El Salvador, Nicaragua, Panama. Introduced in Hawaii.

Condea sect. Laniflorae (Epling) Harley \& J.F.B. Pastore

\section{Key to South American species of Condea sect. Laniflorae}

Indumentum with trichomes dendroid. Petioles $1.3-2.2 \mathrm{~cm}$. Plants of Colombia $\ldots \ldots \ldots \ldots \ldots \ldots$ 8. C. jacobi Indumentum with simple, uniseriate trichomes. Petioles $2-4 \mathrm{~cm}$. Plants of Bolivia and Peru . . . . 9. C. tafallae

8. Condea jacobi (Fern.Alonso) Harley EJ J.F.B.Pastore (2012: 17). 三 Hyptis jacobi Fern.-Alonso (Fernández-Alonso 2010).

DISTRIBUTION. Colombia, Cordillera Oriental.

9. Condea tafallae (Benth.) Harley $\mathcal{E}$ J.F.B.Pastore (2012: 17). 三Hyptis tafallae Benth. (Bentham 1833).

DISTRIBution. Peru - Ayacucho, Cusco, Junin, Pasco. Bolivia - Chuquisaca, Cochabamba, La Paz and Santa Cruz. NOTE. These two species with a large, muchbranched terminal panicle of flowers appear to be related to two Mexican species: Condea iodantha (Epling) Harley \& J.F.B.Pastore and C. subtilis (Epling) Harley \& J.F.B.Pastore. Epling (1949) placed them, together with C. tafallae, into Hyptis sect. Umbellatae Epling.

A recently described Hyptis from northern Mexico (González et al. 2014) is more correctly placed in the genus Condea. González et al. described Hyptis macvaughii J.G.González \& Art.Castro, from Mexico, and assigned it to Hyptis sect. Laniflorae Epling. This section has now been moved, as Condea subsect. 
Laniflorae (Epling) Harley \& J.F.B.Pastore (2012). The following new combination is therefore required:

Condea macvaughii (J.G.González Ẽ Art.Castro) Harley Eे J.F.B.Pastore, comb. nov. $\equiv$ Hyptis macvaughii J.G.González \& Art.Castro, Phytotaxa 163 (3): 158 (2014). Type: Mexico. Nayarit. Compostela: $3.5 \mathrm{~km}$ al O de Las Mesilla por la carretera 200D, rumbo a Las Varas, $15-20 \mathrm{~km}$ antes de llegar a esta población, $285 \mathrm{~m}, 21$ Nov. 2013, J. G. González-Gallegos E̊ A. Castro-Castro 1547 (holotype IBUG, isotypes CIIDIR, ENCB, IEB, MEXU, ZEA).

http://www.ipni.org/urn:lsid:ipni.org:names:77194137-1

The type material has not been seen by the author, but another collection within its known range, but not cited in the original paper: T. B. Croat 45367, Mexico. Nayarit: between Tepic and Puerto Vallarta, 9 Jan. 1979, (K, ex MO), clearly belongs to this taxon and is present in the Kew herbarium.

\section{Acknowledgements}

The author wishes to thank Dr Pedro Viana and colleagues from the Herbarium of the Museu Emilio Goeldi (MG), Belém, staff of the Herbarium of EMBRAPA (IAN) Amazonia Oriental, Belém, and Dr Rafaela Forzza and staff of the Herbarium of the Jardim Botânico, Rio de Janeiro, who loaned me material of the new species of Condea, and Bente Klitgaard and staff at the herbarium and Trishya Long and Julia Buckley in the library at the Royal Botanic Gardens, Kew (K), also many thanks to Ruth Linklater, editorial staff of Kew Bulletin. All these people made the publication of this paper possible! I should also like to thank Juliet Beentje, the artist who drew the excellent plate of Condea petrensis. I am also particularly indebted to Dr Ana Maria Giulietti Harley for reading through the text and suggesting many important improvements, and to the two reviewers, whose critical comments and suggestions did much to improve the paper.

Open Access This article is distributed under the terms of the Creative Commons Attribution 4.0 International License (http://creativecommons.org/licenses/by/4.0/), which permits unrestricted use, distribution, and reproduction in any medium, provided you give appropriate credit to the original author(s) and the source, provide a link to the Creative Commons license, and indicate if changes were made.

\section{Publisher's Note}

Springer Nature remains neutral with regard to jurisdictional claims in published maps and institutional affiliations.

\section{References}

Adanson, M. (1763). Familles des Plantes 2. Vincent, Paris. Bentham, G. (1833). Labiatarum genera et species, pp. 62 - 145. Ridgeway \& Sons, London.

- (1848). Labiatae. In: A. L. P. P. de Candolle (ed.), Prodromus systematis naturalis regni vegetabilis 12: 27 603. V. Masson, Paris.

BFG (2015). Growing Knowledge: an overview of seed plant diversity in Brazil. (Suppl. Angiosperms database: Lamiaceae). Rodriguesia 66: 1085 - 1113.

Briquet, J. (1889). Notes sur quelques labiées américaines. Bull. Soc. Bot. Genève 5: 108 - 121.

(1896). Fragmenta monographiae Labiatarum IV. Labiatae americanae Kuntzeanae. Bull. Herb. Boissier 4: 785 - 808 .

(1897). Contributions à la flore du Paraguay. VII. Labiées. Mem. Soc. Phys. Genève 32, 10: 3 - 45.

(1906). Règles Internationales de la Nomenclature Botaniques adoptees par le Congrès International de Botanique de Vienna 1905. G. Fischer, Jena.

Britton, N. L. (1893). In: T. Morong \& N. L. Britton, An enumeration of the plants collected by Dr Thomas Morong in Paraguay, 1888 - 1890. Ann. New York Acad. Sci. 7: 201.

Browne, P. (1756). The civil and natural history of Jamaica. T. Osborne \& J. Shipton, London.

Endlicher, S. (1838). Genera Plantarum secundum Ordines Naturales disposita. Subtribo III. Hyptideae, pp. 610 - 611. S. Beck, Vienna.

Epling, C. (1936). Synopsis of the South American Labiatae, 3. Repert. Spec. Nov. Regni Veg. Beih. 85: 193 - 288.

(1949). Revisión del género Hyptis (Labiatae). Revista Mus. La Plata, Secc. Bot. 7: 153 - 497.

Fernández-Alonso, J. L. (2010). Una nueve especie de Hyptis (Labiatae) de Colombia. Anales Jard. Bot. Madrid 67: 127 - 135.

González-Gallegos, J. G., Castro-Castro, A., Flores, A. \& Romero-Guzmán, A. R. (2014). Discovery of Hyptis pseudolantana in Jalisco and Michoacán, and description of $H$. cualensis and $H$. macvaughii (Ocimeae, Lamiaceae), two new species from western Mexico. Phytotaxa 163 (3): 149 - 165.

Green, M. L. (1929). Proposed standard-species of nomina generic conservanda. In: International Botanical Congress, Cambridge (England), 1930. Nomenclature. Proposals by British Botanists, pp. 97 - 109. Wyman \& Sons, London.

Harley, R. M. (1971). Pollination in Eriope. An explosive pollination mechanism in Eriope crassipes, a Brazilian Labiate. Biol. J. Linn. Soc. 3: 159 - 164 .

— (1985). Labiadas. 1. Hyptis. In: R. Reitz (ed.), Flora Ilustrada Catarinense 14: 1 - 69. Imprensa Oficial do Estado de Santa Catarina, Jataí.

—- Atkins, S., Budantsev, A., Cantino, P. D., Conn, B., Grayer, R., Harley, M. M., Kok, R. de, 
Krestovskaja, T., Morales, A., Paton, A. J., Ryding, O. \& Upson, T. (2004). Labiatae. In: J. W. Kadereit (ed.), The families and genera of vascular plants 7: 167 - 275. Springer, Berlin \& Heidelberg.

_ \& Pastore, J. F. B. (2012). A generic revision and new combinations in the Hyptidinae (Lamiaceae), based on molecular and morphological evidence. Phytotaxa 58: 1 - 55.

IUCN (2016). Guidelines for Using the IUCN Red List Categories and Criteria, version 12. Cambridge UK. Available from: http://www.iucnredlist.org/documents/RedListGuidelines.pdf Accessed 7 Feb 2017

Jacquin, N. J. (1787, as '1786'). Collectanea ad botanicam, chemiam, et historiam naturalem spectantia, cum figuris 1. Wappler, Vienna.

Kuntze, O. (1891). Revisio Genera Plantarum Vol. 2: 377 - 1011. A. Felix, Leipzig, etc.

Linnaeus, C. (1759). Systema Naturae, ed. 10, 2: 825 1384. L. Salvius, Stockholm.

L'Héritier de Brutelle, C.-L. (1787). Sertum Anglicum, pp. 1 - 36. P. F. Didot, Paris.

O'Leary, N. (2015). Synopsis of Subtribe Hyptidinae (Lamiaceae) in Argentina. Phytotaxa 233 (3): 201 - 235.

Pastore, J. F. B., Harley, R. M., Forrest, F., Paton, A. J. \& van den Berg, C. (2011). Phylogeny of the subtribe Hyptidinae (Lamiaceae tribe Ocimeae) as inferred from nuclear and plastid DNA. Taxon 60: 1317 - 1329.

Poiret, J. L. M. (1805). In: J. B. Lamarck, Encyclopédie méthodique. Botanique 6 (2): 385 - 786. Panckouke, Paris.

Poiteau, P. A. (1806). Monographie du genre Hyptis. Ann. Mus. Natl. Hist. Nat. 7: 459 - 477.

Richard, L. (1792). Catalogus Plantarum ad societatem ineunte anno 1792 e Cayenna missarum a Domino Le Blond. Actes Soc. Hist. Nat. Paris 1: 105 - 114.

Schmidt, J. A. (1858). Labiatae. In: C. F. P. Martius, A. G. Eichler \& N. I. Urban (eds), Flora brasiliensis 8 (1): 67 - 157. Typographia Regia, Munich.

Schrank, F. P. von (1822). Bemerkungen über einige seltnere Pflanzen des k. botanischen Gartens zu München. Denkschr. Königl.-Baier. Bot. Ges. Regensburg 2: 21 - 72.

Stearn, W. T. (2004). Botanical Latin Ed 4. Timber Press, Newton Abbot.

Thiers, B. [continuously updated]. Index Herbariorum: A global directory of public herbaria and associated staff. New York Botanical Garden's Virtual Herbarium. http://sweetgum.nybg.org/science/ih/. 